\title{
Speleothem U-series constraints on scarp retreat rates and landscape evolution: an example from the Severn Valley and Cotswold Hills gull-caves, UK.
}

\author{
Andrew R Farrant ${ }^{* 1}$, Stephen R Noble ${ }^{2}$, A J Mark Barron ${ }^{1}$, Charles A Self ${ }^{3}$ and Stephen R Grebby ${ }^{1}$.
}

${ }^{1}$ British Geological Survey, Keyworth, Nottingham, NG12 5GG.

${ }^{2}$ NERC Isotope Geoscience Laboratory, British Geological Survey, Keyworth, Nottingham, NG12 5GG.

${ }^{3} 4$ Tyne Street, Bristol, BS2 9UA

*Corresponding author (e-mail: arf@bgs.ac.uk)

Words: 8537. 13 Figures. 1 Table.

Cotswolds landscape evolution, UK.

\begin{abstract}
Modeling landscape evolution requires quantitative estimates of erosional processes. Dating erosional landscape features such as escarpments is usually difficult because of the lack of datable deposits. Some escarpments and valley margins are associated with the formation of mass-movement caves, sometimes known as 'gull' or 'crevice' caves, which are typically restricted to within $0.5 \mathrm{~km}$ of the valley margin or scarp edge. As in other caves, these mass-movement cavities may host speleothems. As gull-caves only develop following valley incision, uranium-series dating of speleothems within them can provide a minimum age for the timing of valley excavation and scarp formation. Here we present data from several gull-caves in the Cotswold Hills, which form the eastern flank of the Severn valley in southern England. U-series ages from these gull caves yield estimates for both the minimum age of the Cotswold escarpment and the maximum scarp retreat rate. This is combined with data from geological modeling to propose a model for the evolution of the Severn Valley and the Cotswold Hills. The data suggests that the location of the escarpment and regional topography is determined not by valley widening and scarp retreat, but the in-situ generation of relief by differential erosion.
\end{abstract}

Quantifying rates of landscape processes is an essential requirement for constructing, validating and constraining increasingly sophisticated landscape evolution models (Pazzaglia, 2003; Tucker and Hancock, 2010). With quantitative data, rates of landform development can be evaluated, enabling the relative importance of geomorphological processes to be established and facilitating the development of more realistic landscape evolution models. Moreover, quantification is extremely important in predictive work, as it is required for estimating the impact of future global climate change. Whilst some geomorphological processes can be easily quantified, such as the rate of valley incision by dating river terrace sequences (Maddy, 1997; Maddy and Bridgland 2000; Maddy et al., 2000; Maddy et al., 2001), dating cave levels in carbonate terrains (Farrant et al., 1995; Palmer, 2007), or by dating other alluvial materials such as tufa (Banks et al., 2012), deducing the timing and rates of other processes such as valley widening and escarpment ( or 'scarp') retreat is harder to determine. However, both rates of valley incision and scarp retreat are required to understand how valleys evolve. Do they develop by progressive incision and valley widening through fluvial channel migration and concurrent hill slope retreat or is the gross relief generated 'in-situ' by the progressive removal of the more erodible lithologies over multiple glacial-interglacial cycles? In the latter scenario, valley width is influenced more by lithological heterogeneity and variable susceptibility to periglacial weathering (Murton and Belshaw, 2011), dissolution and mass-movement rather than by fluvial processes. 
Some estimates of scarp retreat have been calculated from dating talus flatirons (also known as tripartite slopes and triangular slope facets), for example Gutiérrez-Elorza and Sesé-Martínez (2001). Fleming et al., (1999) used cosmogenic isotopes to date a basalt escarpment in South Africa. By calculating the exposure age of the escarpment face, they were able to estimate the rate of cliff back-wearing. Another method, proposed here, is to estimate the age of an escarpment by dating mass-movement fissures that, under favorable conditions, develop along the escarpment edge. These fissures, known as gulls, gull-caves (when large enough to enter), windy pits or crevice caves (Halliday, 2004), open up when cambering and mass-movement enable the more competent caprock to move valley-ward following valley incision. These tectonically widened fissures occur in a wide variety of rock types, not just limestone, and are a global phenomenon. Like other caves, these fissures may contain speleothem deposits which can be precisely dated using uranium series methods (Lenart and Pánek, 2013). As the gull-caves can only develop after a scarp has formed, the basal age of the oldest speleothems within them provide a minimum age for cave inception and hence scarp formation. Moreover, as the gull-caves only form close to the scarp edge, they can be used to determine a chronology of scarp retreat. Taken together with rates of valley incision determined from fluvial terraces, the spatial and temporal pattern of valley development and scarp formation can be resolved and models of regional landscape evolution erected.

\section{The study area}

In this paper, we use the lower Severn valley and the Cotswold Hills in southern England (Figure 1) to test this methodology, and then construct a more realistic regional landscape evolution model based on the data. The lower Severn valley between Worcester and Bristol forms a major feature in the British landscape. Its origin and its relationship to the development of rivers such as the Thames draining east to the North Sea has been the subject of debate (Maddy, 2002; Watts et al., 2000, 2005; Lane et al., 2008; Bridgland and Shreve, 2009). Quantifying the rate, timing and mechanisms of valley widening and scarp retreat can help resolve this debate. This requires setting the evolution of the region and the surrounding uplands into a chronological framework. Like many river systems, the timing of valley incision is relatively well-constrained from river terraces; what is less well-known is how the valley morphology developed during this time, particularly around the interfluves away from the main terrace thalweg.

The lower Severn valley is a wide, flat-bottomed vale up to $20 \mathrm{~km}$ wide and typically around $250 \mathrm{~m}$ deep, draining south-west to the Severn Estuary. The western edge of the valley comprises the Malvern Hills and the Forest of Dean. These uplands, underlain by Neoproterozoic and Palaeozoic rocks mark the faulted western margin of the Worcester Basin. Much of the low-lying ground in the centre of the valley, aside from some Palaeozoic rocks exposed north of Bristol, is underlain by Triassic and Lower Jurassic (Lias Group) mudstones (Figure 1) that occupy the core of this basin. The eastern side is marked by the prominent escarpment of the Cotswold Hills (or 'Cotswolds'), which comprise a sequence of gently dipping interbedded limestones and mudstones (Figure 2) of Early to Mid Jurassic (Pliensbachian to Bathonian) age (Barron et al., 2002, 2011). The escarpment extends for about $100 \mathrm{~km}$ between Broadway Hill north-east of Cheltenham south to Bath, rising up to a maximum of $320 \mathrm{~m}$ above sea-level (asl) on its up-dip edge. To the east of the scarp the hills are characterized by a gently sloping, dissected plateau surface around $20 \mathrm{~km}$ wide, cut by numerous deep valleys, especially around Bath and Stroud. Geological mapping clearly shows this topographic surface is not a true stratigraphic dip-slope, and dips at a shallower angle than the bedrock. A few outliers of Middle Jurassic strata, including Bredon Hill, form isolated hills to the west of the main 
escarpment. Around Cheltenham, the top of the Cotswold scarp is capped by the Inferior Oolite Group, here dominated by the Birdlip Limestone Formation. This is a thick succession of ooidal limestones which attains a thickness of $110 \mathrm{~m}$ around Cleeve Hill and thins rapidly to the south and east (Figure 3). North of Cheltenham, several north-south-trending basin-margin faults step down westwards into the Worcester Basin half-graben. These include the Inkberrow Fault which separates the Bredon Hill and Alderton Hill outliers from the main scarp. Ammonite biostratigraphy provides additional evidence for north-south faulting in the Lower Jurassic Lias Group mudstones at the base of the scarp near Cheltenham (Simms, 1990; Donovan et al., 2005). Further south, around Bath, the stratigraphy is subtly different (Figure 2); the Inferior Oolite Group is much thinner (up to $23 \mathrm{~m}$ thick), and the Great Oolite Group caps the main scarp (Barron et al., 2011). The Great Oolite Group comprises the over-consolidated, highly plastic clays of the Fuller's Earth Formation overlain by the massive scarp-forming, ooidal limestones of the Chalfield Oolite Formation, which is up to 35 to 40 $\mathrm{m}$ thick (Figure 2). The regional dip is about $2^{\circ}$ to the south-east, although structures and faults locally modify this.

Superficial deposits are largely confined to the river valleys and low ground (Figure 4). A staircase of sand and gravel river terrace deposits is present along a belt $4 \mathrm{~km}$ wide either side of the River Severn and the River Avon, whilst parts of the Cheltenham area are covered by sand and gravel deposits of composite solifluction, aeolian and fluvial origin. The southern limit of the Anglian glaciation is inferred to extend into the upper part of the Severn Valley, and extensive glacial deposits occur on the higher ground to the north. The later Devensian glaciation was less extensive and glacial deposits of this age are absent from the lower Severn. Most of the Cotswolds remained unglaciated during both major Quaternary ice advances, but nevertheless exposed to severe periglacial conditions.

\section{Mass movement, cambering, and gull-caves}

The interbedded Jurassic limestone and mudstone sequences of the Cotswold Hills are conducive to mass movement. This is particularly evident where river capture has led to greater incision, notably around the city of Bath (Kellaway and Taylor, 1968; Chandler et al., 1976; Hawkins and Privett, 1979; Forster et al., 1987; Hobbs and Jenkins, 2008; Hawkins, 2013) and in the Stroud area. These massmovements include rotational landslides, together with extensive cambering, valley bulging and gull formation. Cambering and associated phenomena (Figure 5) are caused by the gravitational lowering of outcropping or near-surface strata towards an adjacent valley (Parks, 1991). They occur where competent and permeable rocks overlie incompetent and impermeable beds such as mudstone. Following valley incision, the incompetent material is extruded from beneath the cap-rock, initially as a result of stress relief but also due to a reduction in shear strength due to wetting, drying, decalcification and oxidation (Hawkins, 2013). The overlying competent beds develop a local dip or 'camber' towards the valleys due to the loss of support from below, gradually breaking up down slope into more disjointed blocks and draping over the underlying strata (Hollingworth et al., 1944). A valley bulge may develop at the base of the slope due to significant differences in vertical stress between the valley floor and the interfluves. In the competent cap-rocks on the valley flanks or at the crest of the escarpment, gull fractures commonly develop when well-jointed, competent strata become unsupported on their downhill side following mass-movement and valley incision. Extension takes place along joints and bedding planes with bed-over-bed sliding creating voids. When large enough to be explored by cavers, they are termed gull-caves. These are different from normal dissolutionally widened fissures and caves, and can be identified by their distinct morphology. Gulls 
and gull-caves are typically narrow, parallel-sided, joint orientated rifts, often with symmetrically opposing wall morphologies ('fit features' of Self, 1986), but where there has been vertical as well as lateral movement, bedding planes or other discontinuities may also have parted. A comprehensive review of the theories behind cambering, gull and valley bulge formation has been provided by Parks (1991).

Gulls and gull-caves are common throughout the Cotswolds, and are particularly well developed in the Chalfield Oolite Formation around Bath, and in the Birdlip Limestone Formation in the northern Cotswolds (Figure 1). Numerous gulls and well-developed dip-and-fault structures can be observed in many of the old stone mines and quarries in the region, as well as in temporary exposures and construction sites (Hawkins 1980, 2013; Hawkins and Kellaway, 1971; Self, 1986, 1995). Many are well exposed in the extensive stone mines around Bath, especially Box Mine, a suite of complex interlinked pillar-and-stall mines exploiting the Chalfield Oolite Formation, which extends over an area of $6 \mathrm{~km}^{2}$ beneath Box Hill near Corsham. Frequent gulls ranging from a few centimetres to over a metre in width and many tens of metres long are present in a zone up to $600 \mathrm{~m}$ into the hillside (Self and Farrant, 2013). In the southern part of the mine, thirty-five gulls were recorded along a 200 metre transect due east from the entrance, showing an average extension of the strata of just over $5 \%$ along the length of the passage. The evidence from these mines (Self and Farrant, 2013) indicates that gulls and gull-caves are generally restricted to a zone within a few hundred metres of the valley sides, although exceptionally some gulls may occur up to $0.6 \mathrm{~km}$ from the valley margin.

The largest gull-caves are developed in the Claverton Gorge east of Bath, around Dursley and Stroud, and in the Cheltenham-Leckhampton area. Detailed descriptions are available in Self and Boycott $(1999,2004,2005,2011)$. Some of these caves are single gull fissures a few metres long, while others form more extensive systems. Many are partially infilled with fallen boulders or sediment. Locally they contain extensive deposits of speleothem, often coating blocks of limestone or sediment infilling the gull and on the gull walls. The longest gull-cave in the Cotswolds is Sally's Rift [ST 794 650], situated on the east side of the Avon valley near Bathford. This cave, with a surveyed length of 345 metres (Figure 6; Self, 1986, 2008), is a rectilinear network of fissures developed on the dominant local joint directions, $150^{\circ}\left( \pm 10^{\circ}\right)$ and $65^{\circ}\left( \pm 5^{\circ}\right)$ where cambering has occurred in two divergent directions. The furthest accessible fissure is Far Rift, $60 \mathrm{~m}$ from the edge of the hill and (at roof level) around $20 \mathrm{~m}$ below the surface. This is a substantial gull, about a metre wide and up to 10 $\mathrm{m}$ tall. It is well-decorated with calcite speleothem deposits and, at its southern end there are boulders of massive broken speleothem, some of them $0.25 \mathrm{~m}$ thick. Further north, gulls and gullcaves occur in the Birdlip Limestone Formation between Wotton-under-Edge in the south and Broadway in the north, often infilled with collapsed boulders or with calcite-cemented sediment and flowstone. Examples include Dead Man's Quarry near Leckhampton (Figure 7), and Coaley Rift Cave [ST 78679948$] 1 \mathrm{~km}$ north of Uley (Self and Boycott, 2004). This is a large rift passage $16 \mathrm{~m}$ high and $36 \mathrm{~m}$ long, divided into several levels by wedged boulders, and containing many speleothems.

\section{Estimating the age of the Cotswold scarp}

In the Cotswolds, constraining the age of the escarpment has hitherto been problematic. Whilst glacial deposits and fluvial terraces, where they exist, provide an indication of the age of the valley floor, they do not constrain the age of the erosional topography or provide evidence for how the valley morphology develops. There are no talus flatirons that can be dated. Dating the age of the landslides can provide some indication of the age of mass-movement, and thus by implication the 
174 age of the back-scarp feature. Based on slope sections and Holocene alluviation, Privett (1980) postulated that no new large-scale, deep-seated landslides have occurred in the area since the occurred in recent times, but usually as re-activations of existing slides in association with the construction of roads, landscaping, and retaining structures (Forster et al., 1987; Hawkins, 2013). Hutchinson and Coope (2002) obtained a minimum age for a mass movement valley bulge feature by dating overlying fluvial gravels. The bulge, exposed in a dam cut-off trench at the Dowdeswell Dam [SO 988 198], near Cheltenham is covered by later gravels which have been assigned to the Younger Dryas period. Similar spreads of quartzose sand and ooidal limestone gravel, known as the Cheltenham Sand and Gravel, occur at the foot of the scarp around Cheltenham and north to Bredon Hill (Figure 4). These are thought to be composite solifluction and aeolian deposits ('head') of Devensian age (Barron et al., 2002).

In this study we have used the age of speleothems preserved in gull-caves to constrain the age of the Cotswold escarpment. As the opening of these caves is conditional on valley incision and massmovement, speleothems within them must be younger than the scarp. To determine the age and rate of retreat of the Cotswold escarpment, speleothem samples were collected from a number of gull-caves across the region, both on the scarp edge and from sites flanking incised valleys. Care was taken to obtain clean, dense crystalline in-situ speleothem material, focussing on older deposits where it was feasible to determine a stratigraphy. Samples were prepared and analysed at the NERC Isotope Geosciences Laboratory at the British Geological Survey in Keyworth. Material from along single growth horizons was extracted using a dental drill fitted with a diamond-encrusted cutting bit, avoiding recrystallised, corroded or porous material and hiatuses. Where possible, the basal growth layer of each speleothem was sampled, as it is the basal age of the oldest speleothem that provides a minimum age estimate for the cave. By contrast, younger speleothem deposits do not constrain the timing of gull-cave formation, only the timing of drip-water recharge. Where the speleothem was thick enough, two samples were dated to check for stratigraphic consistency. Details of the analytical protocols used are given in Douarin et al., (2014) and briefly summarised here. The subsamples were dissolved in high purity $\mathrm{HNO}_{3}$, and spiked with a mixed ${ }^{229} \mathrm{Th} /{ }^{236} \mathrm{U}$ tracer. No silicate detritus was observed and so further treatment with $\mathrm{HF}-\mathrm{HNO}_{3}-\mathrm{HClO}_{4}$ to ensure total dissolution was not required. After sample/spike equilibration, $U$ and Th were co-precipitated with Fe-hydroxides, and further purified and separated by ion exchange ready for mass spectrometry following Edwards et al., (1988) with modifications. $U$ and Th isotope ratios were measured on a Thermo Scientific Neptune Plus multicollector ICP mass spectrometer in dry plasma mode fitted with a Cetac Aridus II desolvating nebulizer fitted with an ESI PFA Teflon low-uptake rate nebulizer tip. Uranium series isotope ratios and ages are presented in Table 1 and Figure 8. Activity ratio data were calculated from measured atomic ratios and the ${ }^{234} \mathrm{U}$ and ${ }^{230} \mathrm{Th}$ decay constants (see Cheng et al., 2000). Uncertainties are quoted at the 2 sigma level (percent or absolute as indicated). Correction for detrital Th contributions was made using an average continental detritus composition of $\left[{ }^{232} \mathrm{Th} /{ }^{238} \mathrm{U}\right]$ $=1.2 \pm 0.6,\left[{ }^{234} \mathrm{U} /{ }^{238} \mathrm{U}\right]=1.0 \pm 0.5$ and $\left[{ }^{230} \mathrm{Th} /{ }^{232} \mathrm{Th}\right]=1.0 \pm 0.5$. The $\mathrm{U}$ series data (Table 1 ) show that the gull-cave speleothems record carbonate deposition over a large age range, between $49.5 \pm 0.5$ $\mathrm{ka}$ and $346 \pm 19.3 \mathrm{ka}$. Younger speleothems are almost certainly present, but not sampled or dated. Associated with these ages is also a range in relative magnitude of the age uncertainties. These fully propagated uncertainties are controlled primarily by the model detrital Th composition and magnitude of the required correction. The effect of applying the detrital correction is illustrated by 
comparing uncorrected and corrected ages and their associated uncertainties, and is mainly significant for samples where $\left[{ }^{230} \mathrm{Th} /{ }^{232} \mathrm{Th}\right]$ is less than $\sim 20$. The source of detrital Th likely derives from small amounts of limestone substrate incorporated into new growth speleothem. Initial $\left[{ }^{234} \mathrm{U} /{ }^{238} \mathrm{U}\right]$, are mainly close to secular equilibrium $(\sim 1)$ and unremarkable, although BR39 has $\left[{ }^{234} \mathrm{U} /{ }^{238} \mathrm{U}\right]_{\mathrm{i}}=\sim 0.84$ suggesting a source that had been subjected to prior $\mathrm{U}$-removal.

The basal U-series ages obtained here, together with a c. 250 ka age reported for calcite-cemented rubble infilling gull-fissures from a road cutting near Bath University (Hawkins, 2013), and two alphaspectrometric U-series dates of >350 ka from Sally's Rift (Self, 1995), indicate that all the gull-caves were open prior to the last interglacial (MIS 5). In the case of Sally's Rift, Dead Man's Quarry and Catbrain Quarry, the oldest dates (346 $\pm 19 \mathrm{ka}, 348 \pm 15 \mathrm{ka}$, and the less precise $320 \pm 74 \mathrm{ka}$ ), overlap within uncertainty with the MIS $9 / 10$ boundary at c. 337 ka (Lisiecki and Raymo, 2005), and thus predate most of the fluvial terraces exposed in the valley floor. As gull-caves do not generally occur more than a few hundred metres from the hillside, the U-series dates indicate that the scarp edge or valley side has remained in the same approximate location over the last $350 \mathrm{ka}$, a rather surprising conclusion given the present instability of the scarp face (Hawkins, 2013).

Assuming a conservative distance of gull formation of $0.5 \mathrm{~km}$ from the scarp edge, the basal U-series dates from scarp-edge gull-cave speleothems around Cheltenham, at Dead Man's Quarry and Catbrain Quarry, suggest that the rate of scarp retreat over the past 350 ka (i.e. over more than one glacial-interglacial cycle) is at most about $1.42 \mathrm{~m} \mathrm{ka}^{-1}$. A more realistic upper value of c. $0.57 \mathrm{~m}$ $\mathrm{ka}^{-1}$ can be estimated if the cambering and gulls were formed within $200 \mathrm{~m}$ of the escarpment, which is typically what is observed from quarry sections and old mine workings (Self and Farrant, 2013). Clearly, these rates should be treated as maximum values, as speleothem deposition may be initiated a significant time after gull formation. These values are comparable with rates of 0.12 to $1.23 \mathrm{~m} \mathrm{ka}^{-1}$ for Lateglacial and Holocene rock-wall retreat rates on Mynydd Du, a Devonian sandstone escarpment in South Wales (Curry and Morris, 2004), 0.10-0.75 $\mathrm{m} \mathrm{ka}^{-1}$ from Lateglacial and Holocene basalt cliffs in Trotternish, Scotland (Hinchliffe and Ballantyne, 1999) and $0.37 \mathrm{~m} \mathrm{ka}^{-1}$ for a sandstone scarp in Ethiopia (Nyssen et al., 2006) from estimates of annual rock-fall volume. Schmidt (1988) documented similar retreat rates from a number of different cuesta scarps in the Atlas Mountains of Morocco by dating talus relics or sediments in the scarp foreland, or by dating relict gravels on the cuesta back-slope. These values averaged $1.3 \mathrm{~m} \mathrm{ka}^{-1}$ for weak Mio-Pliocene conglomeratic cap-rocks and $0.5 \mathrm{~m} \mathrm{ka}^{-1}$ for more resistant and thicker Palaeogene and Cretaceous limestone cap-rocks analogous to the Jurassic limestones of the Cotswolds. Schmidt (1989) also obtained rates of 0.5 to $6.7 \mathrm{~m} \mathrm{ka}^{-1}$ for Cretaceous scarps on the Colorado Plateau, whilst Cole and Mayer (1982) estimated a rate of retreat of $0.45 \mathrm{~m} \mathrm{ka}^{-1}$ for the Redwall Limestone in the Grand Canyon.

The dates from the sites within the deeply incised river valleys around Bath, notably Sally's Rift, indicate that the Avon Valley had incised through the Chalfield Oolite and a significant distance into the underlying Fuller's Earth mudstone in order to initiate cambering and gull formation prior to MIS 9 (c. $350 \mathrm{ka}$ ). The rate of valley incision cannot be determined with any accuracy as the depth of the valley when cambering was initiated is unknown, as is the time lapse between gull formation and speleothem deposition. However, based on the elevation of the cave, it must be less than c. $0.42 \mathrm{~m}$ $\mathrm{ka}^{-1}$. Similarly, a pre-MIS 5 date is given for the main cambering event at Bath by Chandler et al., 
260 (1976). By inference, the capture of the Thames headwaters by the River (Bristol) Avon was

261 complete by this time (Self, 1995).

\section{Models of valley incision and scarp formation}

263 The evidence for the Pleistocene incision of the Severn valley is recorded in a range of superficial 264 deposits (Figure 4). The area lies beyond the limit of the Devensian glaciation (MIS 2), but the 265 presence of glacial and glaciofluvial deposits including the Wolston Glacigenic Formation (Barron et 266 al., 2002) demonstrate that the southern margin of the Anglian ice-sheet (MIS 12) impinged on the 267 northern part of the area. River terrace deposits are associated with the Severn and Avon rivers. 268 They fall into two formations, the Severn Valley Formation (Maddy et al., 1995) and the 269 Warwickshire Avon Valley Formation (Figure 9). Both comprise six "terrace" members which are 270 dominated by fluvial sand and gravel deposited during cold-stage conditions, plus Holocene 271 alluvium. These terraces have been dated through a mixture of biostratigraphical evidence, an 272 amino acid geochronology, together with marker inputs from three different glaciations (Bridgland 273 et al., 2004). They record the progressive incision of the River Severn and its tributaries during the 274 Middle to Late Pleistocene. The highest fluvial terrace (the Spring Hill Member) is about $50 \mathrm{~m}$ above the present day floodplain and is provisionally correlated with MIS 10. West of the Malverns, an outcrop of pre-Anglian sand and gravel (the Mathon Sand and Gravel Formation) associated with a buried palaeovalley (Barclay et al., 1992) is attributed to the Mathon palaeo-river (Coope et al., 2002). Maddy (2002) suggests that although the timing of terrace aggradations are climatically controlled, the long-term incision of the River Severn appears to be driven by crustal uplift. Based on this data, Maddy (2002) calculated a long-term time-averaged incision rate of $0.15 \mathrm{~m} \mathrm{ka}^{-1}$ over the past $400 \mathrm{ka}$, using the base of the terrace deposits, although rates varied spatially and temporally. However, subsequent to the Anglian glaciation, much of this incision has been restricted to a zone close to the present River Severn, with the present channel occupying a relatively narrow floodplain (typically $<2 \mathrm{~km}$ wide) incised up to 10-15 m into the floor of a much wider (10-20 km) valley. This may reflect a shift in the style of terrace aggradation during the Mid-Pleistocene revolution when climatic fluctuations shifted from 41 ky Milankovitch cycles to stronger 100 ky cycles (Bridgland and Westaway, 2008). This shift led to a change from weak terrace aggradations deposited over several short $41 \mathrm{ky}$ cycles to a period of greater incision and the development of well defined, $100 \mathrm{ky}$ singlecycle terraces.

Whilst the glacial and river terrace deposits clearly demonstrate that the Severn valley was excavated to a significant depth prior to the Anglian glaciation, they do not clarify the style of valley excavation due to their restricted geographical extent. Are the Severn valley and its flanking escarpments a result of scarp retreat or differential erosion - back-stripping or down-wearing (Figure 10)? Combining the rate of valley incision with the rate of scarp retreat derived from U-series dating of gull cave speleothems permits the relative amount of lateral versus vertical erosion to be constrained. The rate of scarp retreat derived from speleothem data is inconsistent with that of valley incision. To generate the present relief of about $300 \mathrm{~m}$ using incision rates of $0.15 \mathrm{~m} \mathrm{ka}^{-1}$ calculated by Maddy (2002) would take about 2.0 Ma. However, the limestone scarp would have only retreated by about $0.56-2.84 \mathrm{~km}$ in this time, far short of the $10-20 \mathrm{~km}$ width of the present valley. Rates of past scarp retreat or valley incision would have to be radically different to achieve the current valley morphology. We suggest the location of the Cotswold escarpment is more likely to be due to lithological (and thus erosional) heterogeneity. If so, it might be expected that facies and 
thickness variations in the more resilient cap-rock would be a significant influence on resulting surface topography. However, there is little gross lateral and vertical variability in the predominantly limestone succession of the Inferior Oolite Group (see e.g. Barron et al., 2002) and an isopachyte map of the group (Figure 3 ) across the Cotswolds shows that it reaches its maximum thickness (110 $\mathrm{m}$ ) in the Cleeve Hill area near Cheltenham, close to the present scarp edge. Clearly the scarp here is not a consequence of the westward thinning of the Inferior Oolite. However, another possibility is that the present location of the escarpment may be a consequence of the prior removal of the Inferior Oolite to the west by a pre-Quaternary erosion surface.

Across much of Southern England, a regional unconformity is present at the base of the Lower Cretaceous. In early Aptian times, the cessation of active crustal extension in the Wessex Basin coincided with the end of a protracted period of erosion (Ruffell, 1992). Across southern England, Aptian and Albian strata - the Upper Greensand and Gault formations - transgressed across the erosion surface, overlapping the faulted basin margins to rest unconformably upon Palaeozoic rocks of the London Platform and south-west England. In south-west England, this unconformity oversteps Jurassic and Triassic strata to rest on Permian rocks on the Haldon Hills at an elevation of 190-200 m (Hancock, 1969). Recent evidence from the Mendip Hills (Farrant et al., 2014) at Tadhill, 25 km south of Bath, demonstrates that the Upper Greensand Formation oversteps the Jurassic strata to rest on Palaeozoic bedrock (Silurian volcanics and Devonian sandstone) at an elevation of c. $280 \mathrm{~m}$ (Figure 1). Given the palaeogeography during the latest Albian (Cope et al., 1992), this erosion surface almost certainly extended across the area of the Cotswolds and Severn Valley, bevelling across the Middle and Upper Jurassic strata. Ruffell (1992) suggests up to 75-100 m of early Albian Gault Clay extended across this region. Circumstantial evidence of a former Cretaceous cover in this area is offered by the presence of flint scatters across the Cotswolds (although possibly of anthropogenic origin) derived from the Upper Cretaceous Chalk Group. Flints and possible Upper Greensand chert occur in high level gravel deposits resting on the Great Oolite around Bath (Donovan, 1995). Although reworked and probably of Quaternary age, these gravels may have been derived from a former Cretaceous cover. Similar deposits also occur in Sally's Rift (Self, 1995) and can be seen in some of the gulls exposed in old stone mines in the area.

The subsequent removal of this Cretaceous cover across Southern England during the Neogene revealed a lithologically variable Jurassic and Lower Cretaceous succession. Initially consequent rivers and streams following the main northwest to southeast drainage alignment in southern England, parallel to the regional tilt of the landmass (Gibbard et al., 2013), were superimposed onto the older bedrock. These drainage systems gradually became reoriented to the underlying geological structure through the effects of multiple glaciations and variable erosion rates, allowing the more resistant lithologies to form uplands. The generalised, gently sloping topographic summit surface on the Cotswolds, which also extends across to the Forest of Dean (Donovan et al., 2005), may be a residual effect of the former extent of the Cretaceous cover. A similar, more pronounced erosion surface is developed further south on the steeply dipping Carboniferous limestones in the Mendip Hills where it forms a conspicuous plateau at around $260-280 \mathrm{~m}$ asl.

Under this proposed scenario, the disposition of the Jurassic rocks, formerly at subcrop beneath the Cretaceous unconformity surface, is inferred to control the location of the present escarpment. Where the harder limestone units were present at subcrop, subsequent denudation would leave these areas upstanding whilst the softer mudrocks would be eroded more rapidly. This denudational 
lowering is likely to be most effective on the less indurated Triassic and Jurassic mudrocks which are particularly susceptible to periglacial effects (Simms, 2004; Murton and Belshaw, 2011), especially during the cold conditions predominant during the Pleistocene. Superimposition of the drainage pattern of the former Cretaceous cover would have also played a role in shaping the relief, possibly helping to create some of the major wind gaps and vales. Concomitant hillslope processes, landsliding and incision by tributary valleys cutting into the upstanding resistant rock-mass would serve to modify the scarp-edge, creating the indented feature we see today. This scenario also explains how the Cotswold Hills are able to maintain their elevation despite limestone denudation rates (predicted from solute concentrations at springs; Goudie, 1990) suggesting that such limestone scarps could not persist for more than one or two million years (Simms, 2004). The presence of a protective siliciclastic Cretaceous cover served to protect the Jurassic limestones from dissolution until relatively recently. There is evidence that some dissolutional lowering has occurred as limestone outcrops towards the scarp edge are more dissected than those further down dip, suggesting more prolonged exposure near the scarp edge. Subsequent flexural unloading due to the erosion of the weak mudrocks in the Severn Valley may have caused uplift of the valley flanks (Watts et al., 2000). This only serves to enhance the relief generated by the large scale removal of softer rock beneath the sub-Cretaceous unconformity. Lane et al., (2008) suggest denudational isostacy may have contributed up to about $50 \%$ of the present-day Cotswolds' relief.

In this model, the distance the scarp has retreated is predicted to be much less than the valley width (Figure 10). If this model is correct, then the initial position of the Cotswold escarpment, as represented by the position of the base of the Inferior Oolite Group at the unconformity subcrop in the Cheltenham area, and the base of the Great Oolite Group around Bath, can be estimated by extrapolating the base of these limestone units up-dip to where they would have intersected the unconformity surface. To determine the geological structure, the base of the Inferior Oolite Group around Cheltenham (here the Birdlip Limestone Formation) was modelled using GSI3D software (Kessler et al., 2009). Data from borehole logs, 1:50 000 scale geological map data and the NEXTMap ${ }^{\text {TM }}$ Britain Digital Terrain Model (DTM) produced by Intermap Technologies were used to construct a series of geological cross sections from which a geological fence diagram was produced. A triangulated irregular network (TIN) surface was then calculated based on mathematical interpolation between the nodes along the drawn sections and the limits of the units, smoothed and contoured (Figure 11). Similarly, the maximum topographic 'summit' surface which approximates to the sub-Cretaceous erosion surface was derived from analysis of the $5 \mathrm{~m}$ NEXTMap ${ }^{\mathrm{TM}}$ Britain DTM. To achieve this, the highest elevations on a $2 \mathrm{~km} \times 2 \mathrm{~km}$ grid were extracted from the DTM and modelled as a TIN surface using the 3D Analyst ArcToolbox (ArcGIS 10.1, ESRI). A planar surface modelling the regional topographic trend - was subsequently merged with the TIN surface to create a generalised Cotswold summit surface extending up-slope to the west beyond the present scarp (Figure 12).

The two surfaces are also shown in a series of cross-sections (Figure 13), and clearly show that the plateau surface dips at a lower angle than the regional stratigraphic dip of $<1^{\circ}$ to the southeast. Extrapolation of these two surfaces west beyond the present escarpment suggests that the base of the Inferior Oolite Group intersects the postulated sub-Cretaceous erosion surface within about 2 to $5 \mathrm{~km}$ of the present escarpment edge. This amount of scarp retreat, based on the minimum rate predicted from gull-cave speleothems, accords well with timescales of valley incision in the lower Severn valley determined by Maddy (2002). The clear anomaly though is Bredon Hill, an outlier of 
the Birdlip Limestone which lies $10 \mathrm{~km}$ from the present scarp and reaches an elevation of $299 \mathrm{~m}$ asl. However, this is separated from the main outcrop by a significant fault, the Inkberrow Fault which downthrows the strata to the west. It is probable that this faulting produced an isolated outlier of the Inferior Oolite Group beneath the sub-Cretaceous erosion surface, which subsequently was left upstanding by the denudation of the surrounding mudstone. Similarly, the large Inferior Oolite outlier on Dundry Hill south of Bristol lies on a synclinal axis. This syncline is inferred to have preserved the Inferior Oolite Group beneath the Cretaceous unconformity whilst in the surrounding area it was removed by intra-Cretaceous erosion. In the north-east of the region, the Inferior Oolite Group thins rapidly to the east across the Vale of Moreton axis (which is the manifestation at the surface of the system of faults forming the eastern margin of the Worcester Basin). The lower part of the Group including the Birdlip Limestone was removed by intra-Bajocian erosion. This structure causes the base of the Inferior Oolite Group to rise up and intersect the sub-Cretaceous erosion surface, allowing subsequent denudation to generate a second east-facing escarpment, creating the Vale of Moreton.

\section{Conclusions}

Erosional landforms such as the valley margins and escarpments have traditionally been hard to date due to the lack of datable deposits associated with them. Dating speleothems contained in massmovement gull-caves is a new technique which can be used to estimate the minimum age of an escarpment and determine maximum rates of scarp retreat, and which is applicable wherever gullcaves are present. The application of this methodology to the lower Severn valley and the Cotswold Hills, combined with data from fluvial terraces and other superficial deposits has enabled a better model of regional landscape evolution to be deduced. The data obtained from gull-caves demonstrates that the Cotswold escarpment has retreated less than $0.5 \mathrm{~km}$ during the last c. $350 \mathrm{ka}$. Given rates of valley incision determined from fluvial terraces along the River Severn and scarp retreat rates determined from these gull-caves, we suggest that valley widening by scarp retreat was not the dominant process in the development of the regional topography. Instead, we propose that the relief is generated by differential erosion of the heterogeneous bedrock succession, enabling the Cotswold escarpment to develop 'in situ'. The present location of the scarp is most probably controlled by the exhumation of more resistant ooidal limestone units from beneath a subCretaceous unconformity. Modelling of topographic and bedrock surfaces in the Cheltenham area suggests that the Cotswold scarp has retreated less than $5 \mathrm{~km}$ since these rocks were exhumed, and that the outliers of Middle Jurassic strata such as Bredon Hill and Dundry Hill are preserved as downthrown fault blocks or in synclinal axes.

\section{Acknowledgments}

We would like to thank the reviewers for constructive reviews which helped improve this paper. Farrant, Noble, Barron, and Grebby publish with the approval of the Executive Director of the British Geological Survey. Mr. Neil Boulton and Dr. Diana Sahy of NIGL are thanked for their assistance with U-series sample preparation and chemistry.

\section{References}


Banks, V.J., Jones, P.F., Lowe, D.J., Lee, J.R., Rushton, J. \& Ellis, M.A. 2012. Review of tufa deposition and palaeohydrological conditions in the White Peak, Derbyshire, UK: implications for Quaternary landscape evolution. Proceedings of the Geologists' Association, 123, 117-129.

Barclay, W.J., Brandon, A., Ellison, R.A. \& Moorlock, B.S.P. 1992. A Middle Pleistocene palaeovalleyfill west of the Malvern Hills. Journal of the Geological Society, 149, 75-92.

Barron, A.J.M., Sumbler, M.G. \& Morigi, A.N. 2002. Geology of the Moreton-in-Marsh district. Sheet description of the British Geological Survey, 1:50 000 Sheet 217 Moreton-in-Marsh (England and Wales). British Geological Survey, Keyworth.

Barron, A.J.M., Sheppard, T.H., Gallois, R.W., Hobbs, P.R.N. \& Smith, N.J.P. 2011. Geology of the Bath district. Sheet Explanation of the British Geological Survey. 1:50 000 Sheet 265 Bath (England and Wales). British Geological Survey, Keyworth.

Bridgland, D.R., Maddy, D. \& Bates, M. 2004. River terrace sequences: templates for Quaternary geochronology and marine-terrestrial correlation. Journal Quaternary Science, 19, 1-16.

Bridgland, D.R. \& Westaway, R. 2008. Climatically controlled river terrace staircases: a worldwide Quaternary phenomenon. Geomorphology, 98, 285-315.

Bridgland, D.R. \& Schreve, D.C. 2009. Implications of new Quaternary uplift models for correlation between the Middle and Upper Thames terrace sequences, UK. Global and Planetary Change, 68, 346-356.

Chandler, J.H., Kellaway, G.A., Skempton, A.W. \& Wyatt, R.J. 1976. Valley slope sections in Jurassic strata near Bath, Somerset. Philosophical Transactions of the Royal Society of London, Series A, 283, 527-556.

Cheng, H., Edwards, R.L., Hoff, J., Gallup, C.D., Richards, D.A. \& Asmerom, Y. 2000. The half-lives of uranium-234 and thorium-230. Chemical Geology, 169, 17-33.

Cole, K.L. \& Mayer, L. 1982. Use of packrat middens to determine rates of cliff retreat in the eastern Grand Canyon, Arizona. Geology, 10, 597-599.

Coope, G.R., Field, M.H., Gibbard, P.L., M, G. \& Richards, A.E. 2002. Palaeontology and biostratigraphy of Middle Pleistocene river sediment in the Mathon Member, at Mathon, Herefordshire, England. Proceedings of the Geologists' Association, 113, 237-258.

Cope, J.C.W., Ingham, J.K. \& Rawson, P.F. 1992. Atlas of Palaeogeography and Lithofacies. Geological Society, London

Curry, A.M. \& Morris, C.J. 2004. Lateglacial and Holocene talus slope development and rockwall retreat on Mynydd Du, UK. Geomorphology, 58, 85-106.

Donovan, D.T. 1995. High level drift deposits East of Bath. Proceedings of the University of Bristol Spelaeological Society, 20, 109-126.

Donovan, D.T., Curtis, M.L.K. \& Fry, T.R. 2005. The lower part of the Lias Group in south Gloucestershire: zonal stratigraphy and structure. Proceedings of the Geologists' Association, 116, 45-59.

Douarin, M., Elliot, M., Noble, S.R., Sinclair, D., Henry, L.-A., Long, D., Moreton, S.G. \& Murray Roberts, J. 2013. Growth of North-East Atlantic Cold-Water Coral Reefs and Mounds during the Holocene: A High Resolution U-Series and ${ }^{14} \mathrm{C}$ Chronology. Earth and Planetary Science Letters, 375, 176-187.

Edwards, R.L., Chen, J.H. \& Wasserburg, G.J. 1988. ${ }^{238} \mathrm{U}-{ }^{234} \mathrm{U}-{ }^{230}$ Th- ${ }^{232}$ Th systematics and the precise measurement of time over the past 500,000 years. Earth and Planetary Science Letters, 81, 175-192. 
472 Farrant, A.R., Smart, P.L., Whitaker, F.F. \& Tarling, D.H. 1995. Long-term Quaternary uplift rates

473 inferred from limestone caves in Sarawak, Malaysia. Geology, 23, 357-360.

474 Farrant, A.R., Vranch, R.D., Ensom, P.C., Wilkinson, I.P. \& Woods, M.A. 2014. New evidence of the

475 Cretaceous overstep of the Mendip Hills, Somerset, UK. Proceedings of the Geologists' Association,

$476125,63-73$.

477 Fleming, A., Summerfield, M.A., Stone, J.O., Fifield, L.K. \& Cresswell, R.G. 1999. Denudation rates for 478 the southern Drakensberg escarpment, SE Africa, derived from in-situ-produced cosmogenic 36Cl:

479 initial results. Journal of the Geological Society, 56, 209-212.

480 Forster, A., Hobbs, P.R.N., Wyatt, R.J. \& Entwisle, D.C. 1987. Environmental geology maps of Bath 481 and the surrounding area for engineers and planners. Geological Society, London, Engineering

482 Geology Special Publications, 4, 221-235

483 Gibbard, P.L., Turner, C. \& West, R.G. 2013. The Bytham river reconsidered. Quaternary

484 International, 292, 15-32.

485 Goudie, A.S. 1990. The Landforms of England and Wales. Blackwell, Oxford.

486 Green, G.W. 1992. Bristol and Gloucester Region. 3rd ed. Her Majesty's Stationary Office, London.

487 Gutierrez Elorza, M. \& Sesé Martínez, V.H. 2001. Multiple talus flatirons, variations of scarp retreat

488 rates and the evolution of slopes in Almazán Basin (semi-arid central Spain). Geomorphology, 38, 19-

48929

490 Halliday, W.R. 2004. Pseudokarst. In: Gunn, J. (ed.) Encyclopedia of caves and karst science. Fitzroy

491 Dearborn, London, 604-608.

492 Hancock, J.M. 1969. The transgression of the Cretaceous sea in south-west England. Proceeding of

493 the Geologists' Association, 100, 565-594

494 Hawkins, A.B. 1980. Geology and its implications for the municipal building surveyor. Municipal

495 Building Surveyors Annual Conference and Symposium, Bath, 23-29.

496 Hawkins, A.B. 2013. Engineering significance of superficial structures and landslides in the Bath area, 497 UK. Bulletin of Engineering Geology and the Environment, 72, 353-370.

498 Hawkins, A.B. \& Kellaway, G.A. 1971. Field Meeting at Bristol and Bath with special reference to new evidence of glaciation. Proceedings of the Geologists' Association, 82, 267-292.

Hawkins, A.B. \& Privett, K.D. 1979. Engineering geomorphological mapping as a technique to elucidate areas of superficial structures; with examples from the Bath area of the south Cotswolds. Quarterly Journal of Engineering Geology, 12, 221-233.

Hinchliffe, S. \& Ballantyne, C.K. 2009. Talus structure and evolution on sandstone mountains in NW Scotland. The Holocene, 19, 477-486.

Hobbs, P.R.N. \& Jenkins, G.O. 2008. Bath's 'foundered strata' - a reinterpretation. British Geological Survey Report OR/08/052.

Hollingworth, S.E., Taylor, J.H. \& Kellaway, G.A. 1944. Large-scale superficial structures in the

509 Hutchinson, J.N. \& Coope, G.R. 2002. Cambering and valley bulging, periglacial solifluction and 510 Lateglacial Coleoptera at Dowdeswell, near Cheltenham. Proceedings of the Geologists' Association, 511 113, 291-300. 
512 Kellaway, G.A. \& Taylor, J.H. 1968. The influence of land-slipping on the development of the City of 513 Bath, England. In: Malkovský, M. (ed.) XXIII International Geological Congress. Academia, Prague, 514 Czechslovakia, 65-76.

515 Kessler, H., Mathers, S.J. \& Sobisch, H.-G. 2009. The capture and dissemination of integrated 3D 516 geospatial knowledge at the British Geological Survey using GSI3D software and methodology. 517 Computers \& Geosciences, 35, 1311-1321.

518 Lane, N.F., Watts, A.B. \& Farrant, A.R. 2008. An analysis of Cotswold topography: insights into the 519 landscape response to denudational isostasy. Journal of the Geological Society, 165, 85-103.

520 Lenart, J. \& Pánek, T. 2013. Crevice-type caves as indicators of slope failures: a review paying a 521 special attention to the flysch Carpathians of Czechia, Poland, and Slovakia. Acta Universitatis 522 Carolinae Geographica, 48, 35-50.

523 Lisiecki, L.E. \& Raymo, M.E. 2005. A Pliocene-Pleistocene stack of 57 globally distributed benthic ${ }^{18} \mathrm{O}$ 524 records. ,20, PA1003, DOI: 10.1029/2004PA001071. Paleoceanography, PA1003.

525 Maddy, D. 1997. Uplift-driven valley incision and river terrace formation in southern England. 526 Journal of Quaternary Science, 12, 539-545.

527 Maddy, D. 2002. An evaluation of climate, crustal movement and base level controls on the Middle528 Late Pleistocene development of the River Severn, UK. Geologie en Mijnbouw, 81, 329-338.

529 Maddy, D., Green, C.P., Lewis, S.G. \& Bowen, D.Q. 1995. Pleistocene geology of the lower Severn 530 Valley, UK. Quaternary Science Reviews, 14, 209-222.

531 Maddy, D. \& Bridgland, D.R. 2000. Accelerated uplift resulting from Anglian glacioisostatic rebound 532 in the Middle Thames valley, UK: evidence from the terrace record. Quaternary Science Reviews, 19, 533 1589-1604.

534 Maddy, D., Bridgland, D.R. \& Green, C.P. 2000. Crustal uplift in southern England; evidence from the 535 river terrace records. Geomorphology, 33, 167-181.

536 Maddy, D., Bridgland, D.R. \& Westaway, R. 2001. Uplift-driven valley incision and climate-controlled 537 river terrace development in the Thames valley, UK. Quaternary International, 79, 23-36.

538 Murton, J.B. \& Belshaw, R.K. 2011. A conceptual model of valley incision, planation and terrace 539 formation during cold and arid permafrost conditions of Pleistocene southern England. Quaternary 540 Research, 75, 385-394.

541 Nyssen, J., Poesen, J., Moeyersons, J., Deckers, J. \& Haile, M. 2006. Processes and rates of rock 542 fragment displacement on cliffs and scree slopes in an amba landscape, Ethiopia. Geomorphology, 543 81, 265-275.

544 Palmer, A.N. 2007. Cave geology. Cave books, Dayton.

545 Parks, C.D. 1991. A review of the mechanisms of cambering and valley bulging. In: Forster, A., 546 Culshaw, M., Cripps, J.C., Little, J.A. \& Moon, C.F. (eds.) Quaternary Engineering Geology. Geological 547 Society of London.

548 Pazzaglia, F.J. 2003. Landscape evolution models. Developments in Quaternary Sciences, 1, 247-274.

549 Privett, K.D. 1980. The engineering geology of slopes in the south Cotswolds. Ph.D. Thesis, University 550 of Bristol.

551 Ruffell, A.H. 1992. Early to mid-Cretaceous tectonics and unconformities of the Wessex Basin 552 (southern England). Journal of the Geological Society, 149, 443-454. 
553 Schmidt, K.-H. 1988. Rates of scarp retreat: A means of dating Neotectonic activity. In: Jacobshagen, 554 V. (ed.) The Atlas System of Morocco. Springer Berlin Heidelberg, Lecture Notes in Earth Sciences, 555 445-462.

556 Schmidt, K.H. 1989. The significance of scarp retreat for Cenozoic landform evolution on the 557 Colorado Plateau, USA. Earth Surface Processes and Landforms, 14, 93-105.

558 Self, C.A. 1986. Two gull-caves from the Wiltshire/Avon border. Proceedings of the University of 559 Bristol Spelaeological Society, 17, 153-174.

560 Self, C.A. 1995. The relationship between the gull-cave Sally's Rift and the development of the River 561 Avon east of Bath. Proceedings of the University of Bristol Spelaeological Society, 20, 91-108.

562 Self, C.A. 2008. Cave passages formed by a newly recognised type of mass movement: a gull tear.

563 Proceedings of the University of Bristol Spelaeological Society, 24, 101-106.

564 Self, C.A. \& Boycott, A. 1999. Landslip caves of the Southern Cotswolds. Proceedings of the University 565 of Bristol Spelaeological Society, 21, 197-214.

566 Self, C.A. \& Boycott, A. 2004. Landslip caves of the Middle Cotswolds. Proceedings of the University 567 of Bristol Spelaeological Society, 23, 97-117.

568 Self, C.A. \& Boycott, A. 2005. Landslip caves of the Northern Cotswolds. Proceedings of the University 569 of Bristol Spelaeological Society, 24, 53-70.

570 Self, C.A. \& Boycott, A. 2011. Cotswolds Cave Notes. Proceedings of the University of Bristol

571 Spelaeological Society, 25, 249-251

572 Self, C.A. \& Farrant, A.R. 2013. Gulls, gull-caves and cambering in the southern Cotswold Hills, 573 England. In: Filippi, M. \& Bosak, P. (eds.) 16th International Congress of Speleology Vol. 3. Czech 574 Speleological Society, Brno, Czech Republic, 132-136.

575 Simms, M.J. 1990. Upper Pliensbachian stratigraphy in the Severn Basin area: evidence for 576 anomalous structural controls in the Lower and Middle Jurassic. Proceedings of the Geologists' 577 Association, 101, 131-144.

578 Simms, M.J. 2004. Tortoises and hares: dissolution, erosion and isostasy in landscape evolution.

579 Earth Surface Processes and Landforms, 29, 477-494.

580 Tucker, G.E. \& Hancock, G.R. 2010. Modelling landscape evolution. Earth Surface Process and 581 Landforms, 35, 28-50.

582 Watts, A.B., McKerrow, W.S. \& Fielding, E. 2000. Lithospheric flexure, uplift, and landscape evolution 583 in south-central England. Journal of the Geological Society, 157, 1169-1177.

584 Watts, A.B., McKerrow, W.S. \& Richards, K. 2005. Localized Quaternary uplift of south-central 585 England. Journal of the Geological Society, 162, 13-24.

586 Westaway, R., Maddy, D. \& Bridgland, D.R. 2002. Flow in the lower continental crust as a mechanism 587 for the Quaternary uplift of south-east England: constraints from the Thames terrace record.

588 Quaternary Science Reviews, 21.

Figures:

591 Figure 1. Geological map of the Cotswold Hills region, England. Known gulls and gull-caves are shown 592 as circles, whilst gull-caves which have been dated in this study are shown as stars. NEXTMapTM 593 Britain elevation data from Intermap Technologies. See the online version for a colour version. 
594 Figure 2. Geological section though the Jurassic sequence in the Cheltenham area (A) and around

595 Bath (B) showing the differences in local stratigraphy.

596 Figure 3. Isopach map of the Inferior Oolite Group in the Cotswold Hills (modified from Green, 1992, 597 fig. 27). Contours are in metres.

598 Figure 4. Superficial deposits in the Cotswold region, including river terrace deposits in the Severn, 599 Warwickshire Avon and upper Thames valleys, and glacial till in the north and west. Orange areas 600 are river terraces, blue and pink are glacial and glaciofluvial sediments respectively and yellow 601 alluvium. The red line marks the inferred limit of the Anglian glaciation, whilst the blue is the limit of 602 the Devensian glaciation. NEXTMap ${ }^{\mathrm{TM}}$ Britain elevation data from Intermap Technologies. See the 603 online version for a colour version.

604 Figure 5. Section through an idealised Cotswold hillslope showing major features of cambering, gull 605 formation and valley bulge.

606 Figure 6 Survey of Sally's Rift and other caves in Gully Wood (after Self, 1986). Speleothem samples 607 were collected from the southern end of Far Rift.

608 Figure 7. Dead Man's Quarry, Leckhampton, looking west [SO 9464 1772]. The cliff face in the Birdlip 609 Limestone clearly displays numerous vertical gull fractures, from one of which a speleothem sample 610 was obtained. The main Cotswold escarpment is located less than $200 \mathrm{~m}$ behind the far end of the 611 quarry.

612 Figure 8. Isochrons for the U-series samples from the Cotswold gull caves.

613 Figure 9. Idealised transect through the Severn-Avon terrace sequence. Severn nomenclature is 614 applied where possible. Correlations with the marine isotope record are indicated. Modified from 615 Bridgland et al. (2004).

616 Figure 10. Cross sections across the Sevren valley and the Cotswold escarpment under different 617 models of landscape evolution. A. Valley cross section derived by valley incision and widening in 618 response to fluvial incision, lateral channel migration and hillslope retreat at times $t=1-4$. $B$.

619 Topography derived by differential erosion beneath a sub-Cretaceous unconformity at times $\mathrm{t}=1-4$.

620 Figure 11. Generalised contours (metres above sea-level) for the base of the Inferior Oolite Group 621 (Birdlip Limestone Formation) in the northern Cotswolds, based on 3D geological modelling. The 622 steep dips along the southern margin of the model are an artefact of the model boundary. The 623 locations of the cross sections shown in Figure 13 are shown. Base map contains Ordnance Survey 624 data (C) Crown Copyright and database rights 2014. See the online version for a colour version.

625 Figure 12. Generalised contours for the Cotswold summit surface in the northern Cotswolds 626 superimposed on the modelled base Inferior Oolite Group and extended across the Severn valley. 627 Base map contains Ordnance Survey data (C) Crown Copyright and database rights 2014. See the 628 online version for a colour version.

629 Figure 13. Cross sections across the northern Cotswolds, showing the disparity between the 630 Cotswold Summit surface (purple) and the base of the Inferior Oolite Group (Birdlip Limestone 631 Formation - blue). Location of the sections is shown in Figure 11. See the online version for a colour 632 version. 
633 Table 1. U-series and age data for speleothem samples collected from the gull-caves along the 634 Cotswold escarpment and in the Avon valley. 


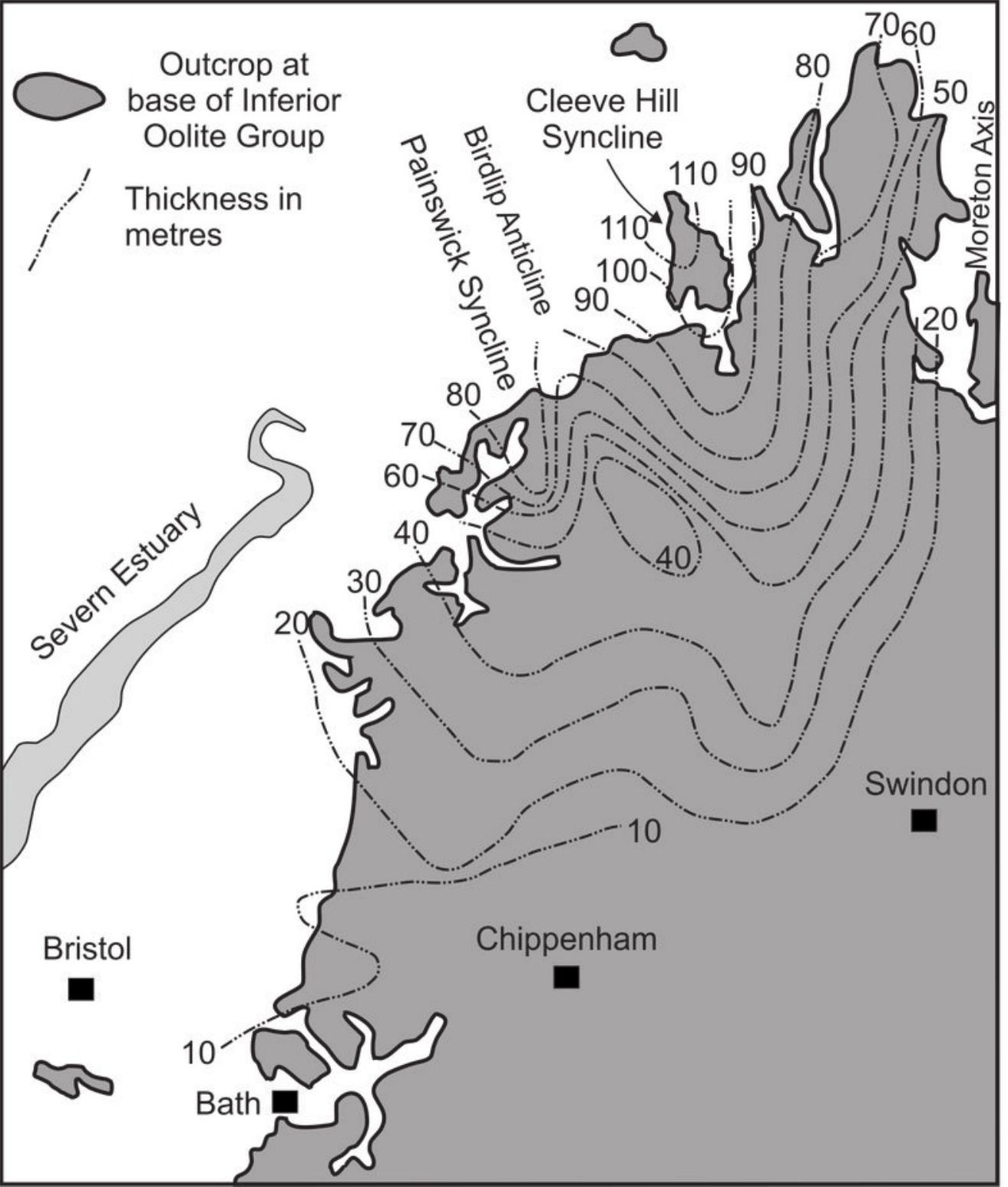


Forest Marble Fm

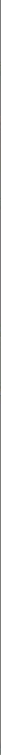


Gully Wood Cave No. 5

(after Self (UBSS) 1999)
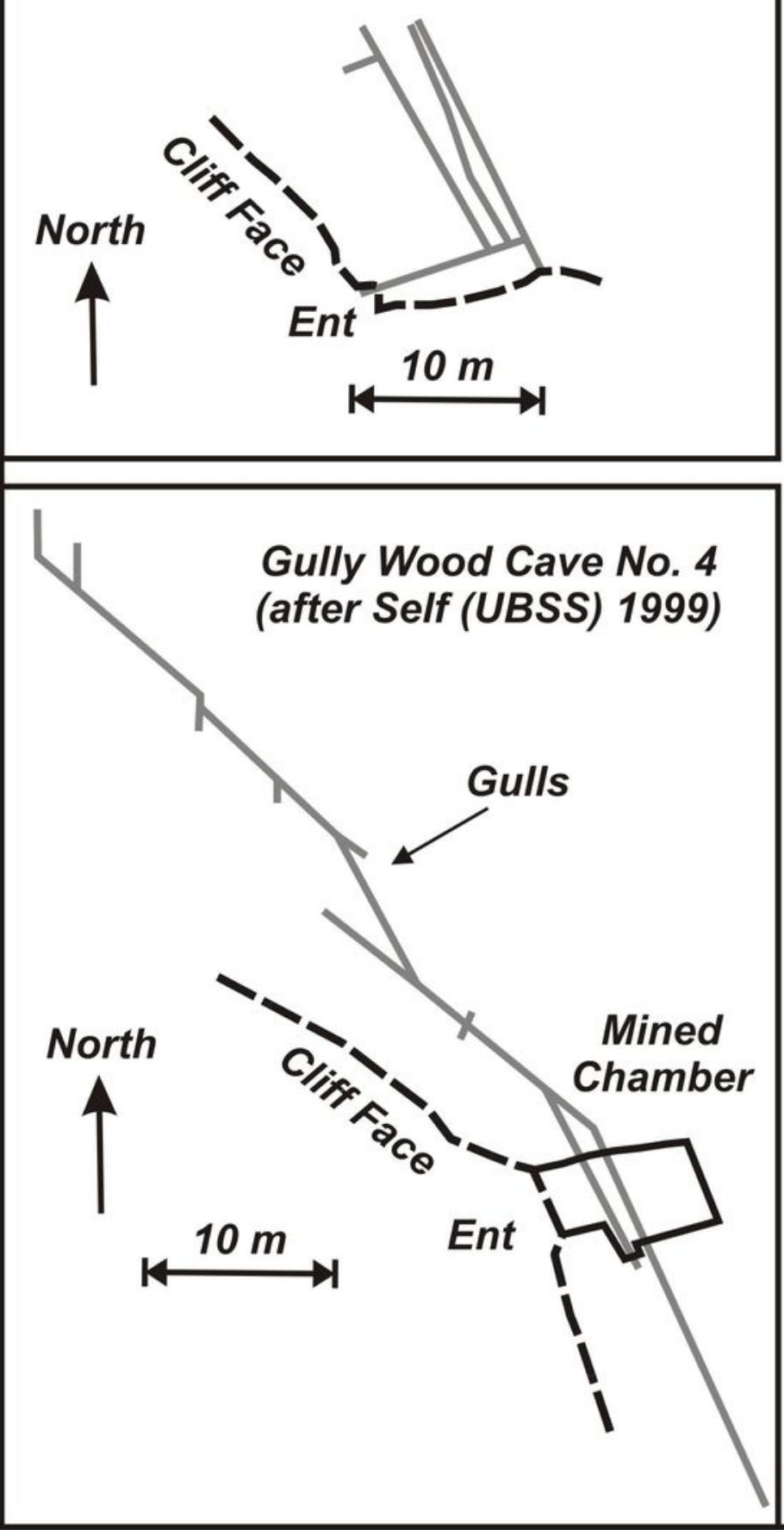

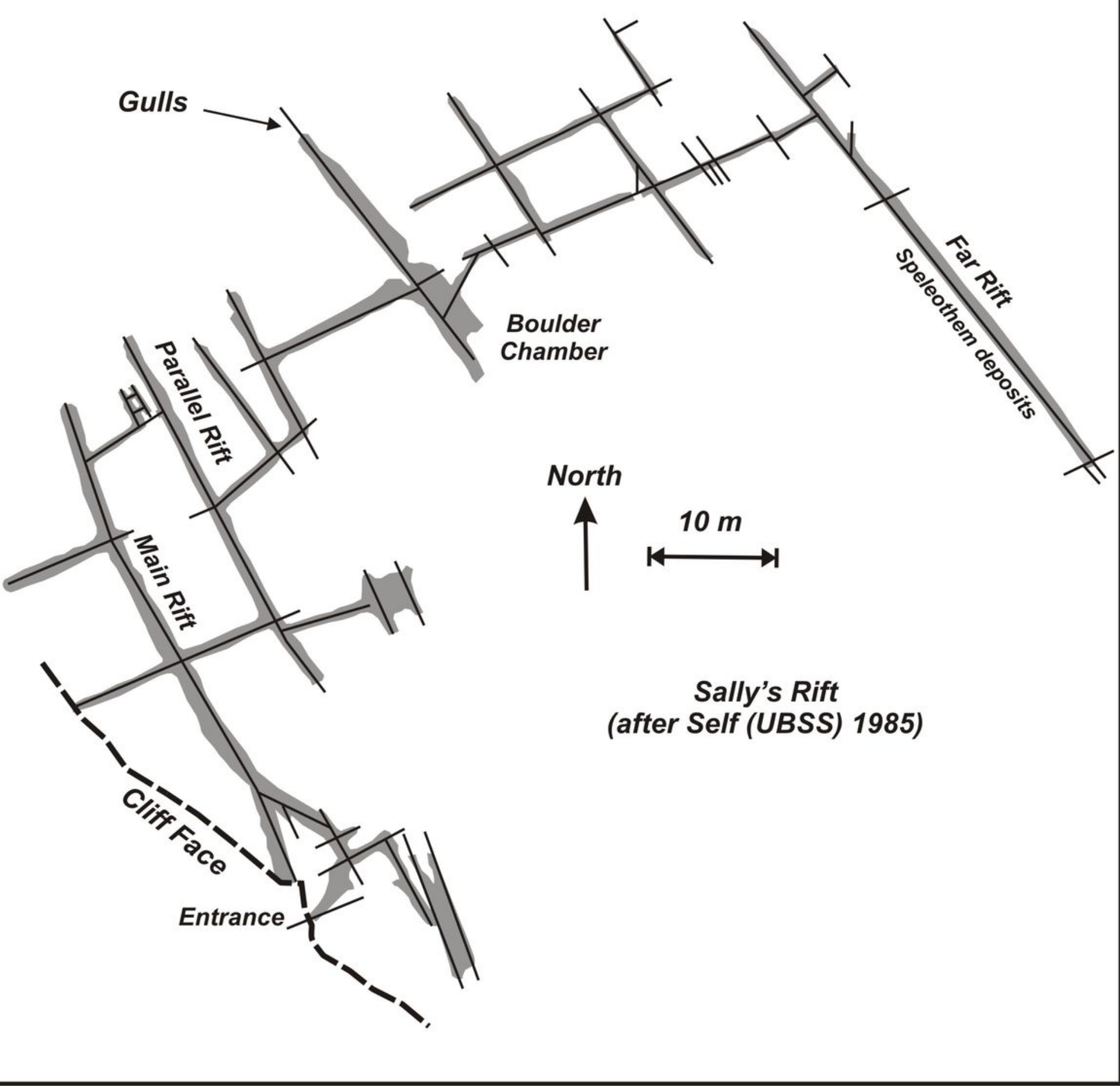


















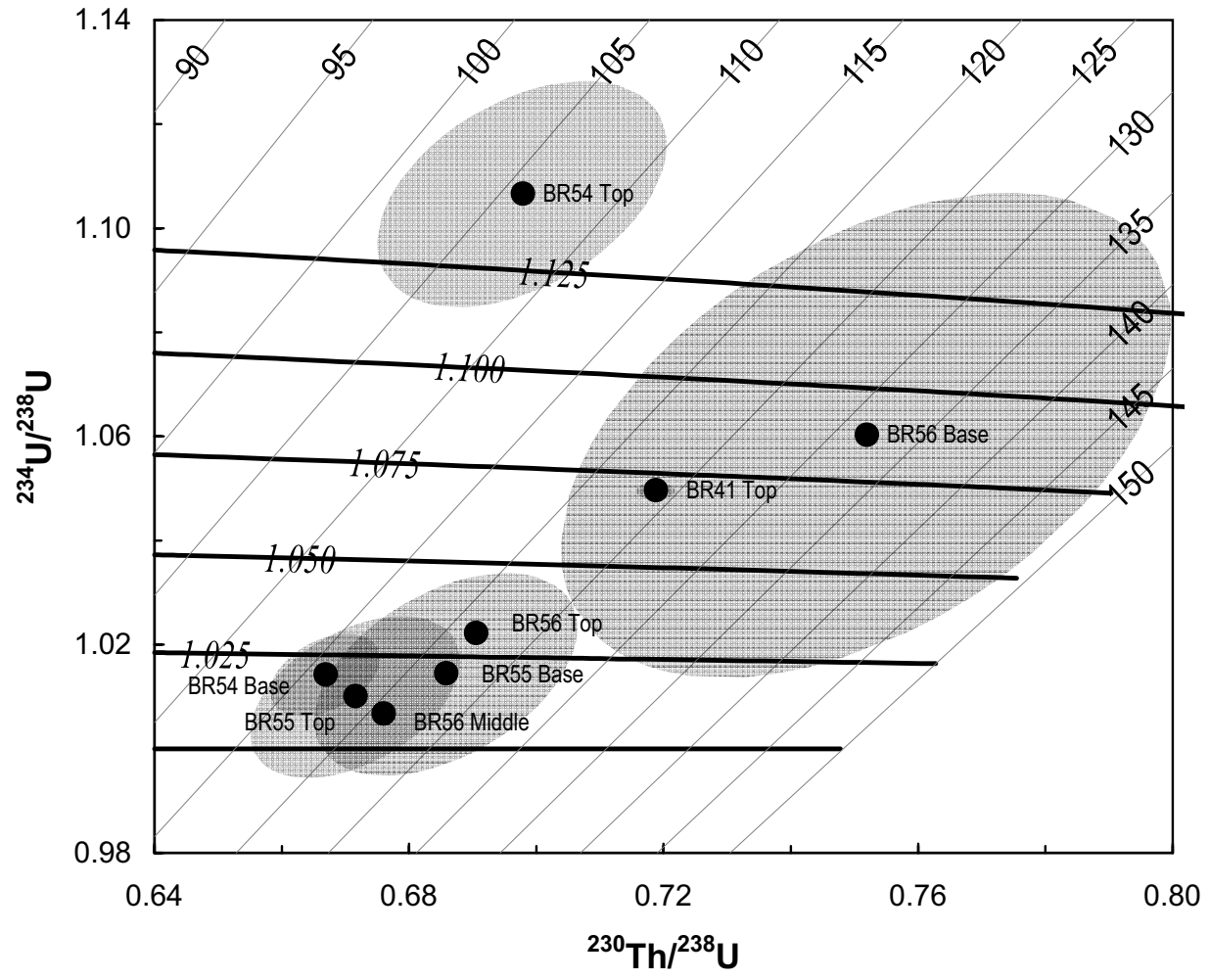




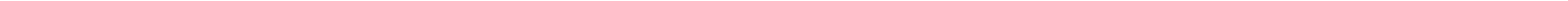




\section{A. Model 1.}

Gradual valley incision and concurrent widening by lateral channel migration and slope retreat at times $\mathrm{t}=1$ to 4

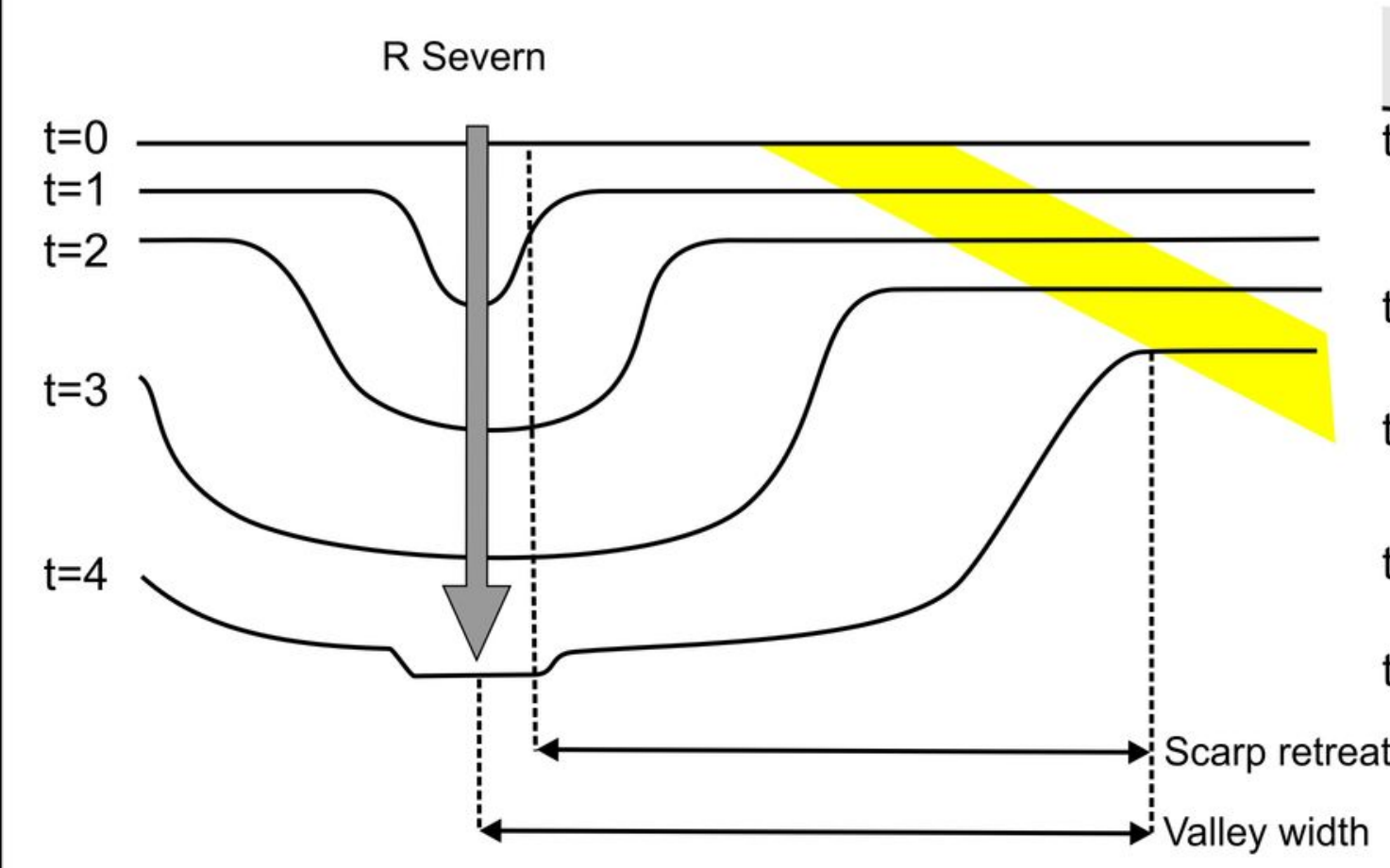

B. Model 2.

Topography generated 'in-situ' by differential erosion of hard and soft lithologies beneath sub-Cretaceous unconformity at times $t=1$ to 4

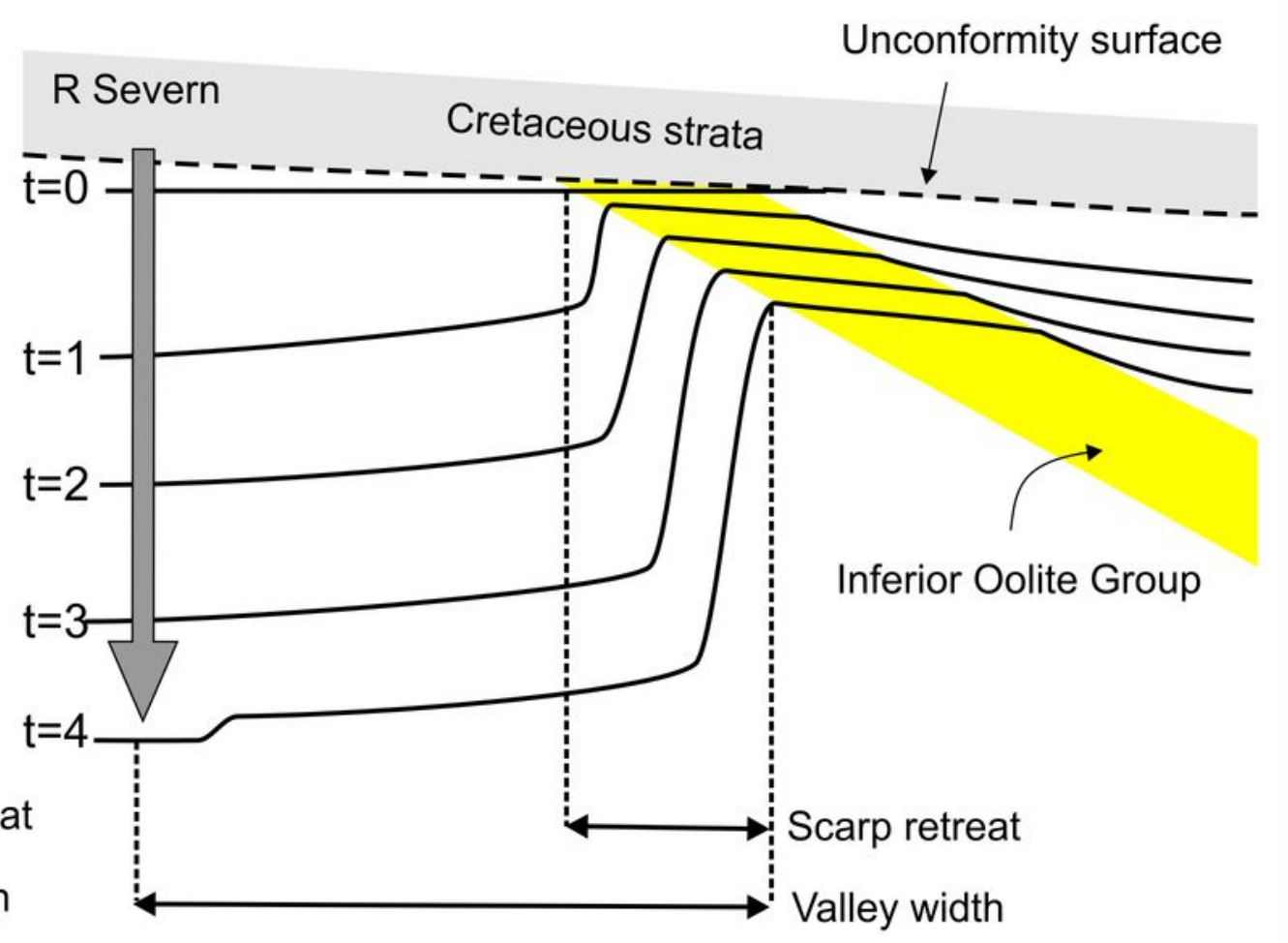




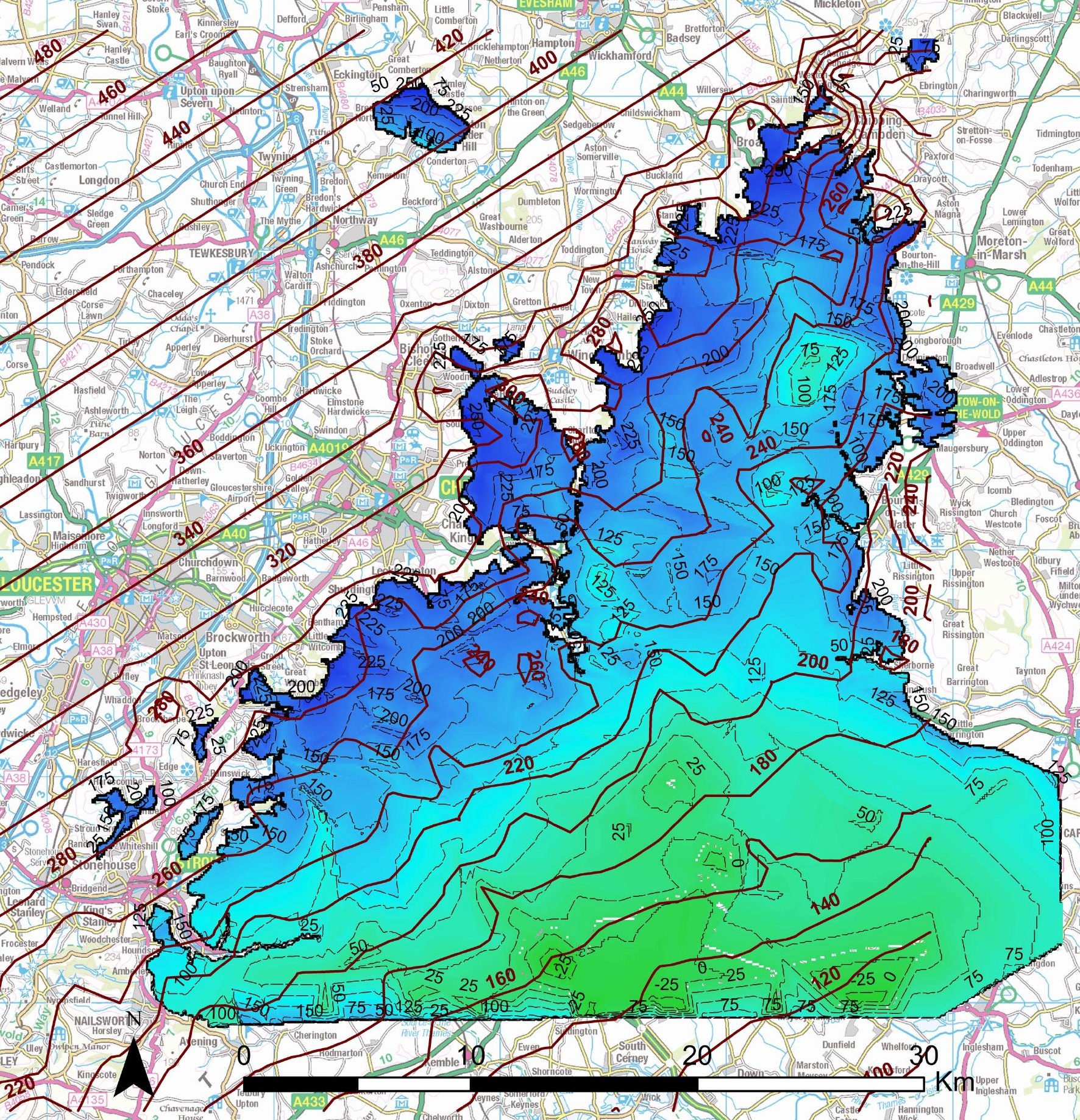


Table 1. Gull Caves speleothem U-Th isotope data

Sample

Concentration

$U(\mathrm{ng} / \mathrm{g})^{\dagger} \quad{ }^{232} \mathrm{Th}(\mathrm{ng} / \mathrm{g})^{\dagger} \quad\left[{ }^{230} \mathrm{Th} /{ }^{232} \mathrm{Th}\right]^{\dagger}$

\section{Ratios Corrected for detritial Th}

BR 11, banded flowstone from Far Rift, Sally's Rift, Chalfield Oolite, [ST 794 650]

BR11 Top

$29.01 \pm 0.1 \quad 8.608 \pm 0.3$

$11.8 \pm 0.4$

$1.167 \pm 3.9$

$\left[{ }^{234} \mathrm{U} /{ }^{238} \mathrm{U}\right.$

$1.175 \pm 3.8$
Age (ka,

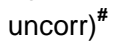

0.51

$326.9 \pm 9.2$

$0.9596 \pm 0.40$

$196.2 \pm 0.2 \quad 0.3614 \pm 0.3$

$1581 \pm 0.4$

$58.1 \pm 0.4$

$1469 \pm 0.4$

$4105 \pm 0.4$

$2688 \pm 0.4$

$0.4441 \pm 0.90 \quad 1.201 \pm 0.30 \quad 0.28 \quad 50.1 \pm 0.2$

$0.5271 \pm 0.35 \quad 0.8781 \pm 0.13 \quad 0.01 \quad 102.9 \pm 0.7$

$0.6253 \pm 0.34-1.328+0.11 \quad 0.00 \quad 67.2 \pm 0.3$

$0.7188 \pm 0.35 \quad 1.050 \pm 0.13 \quad 0.00 \quad 123.8 \pm 0.9$

calcite from a pool deposit, Top

$1321 \pm 0.1 \quad 0.6106 \pm 0.3$

BR41 flowstone on passage wall, Top

$211.8 \pm 0.1 \quad 0.1719 \pm 0.3$

BR 45 flowstone from gull-cave wall, Catbrain Quarry, Birdlip Limestone, [SO 867 114].

BR45 Base

$209.3 \pm 0.1 \quad 4.499 \pm 0.1 \quad 140.7 \pm 0.3$

BR45 Top

$256.8 \pm 0.3$

$0.9970 \pm 0.48$

$0.9706 \pm 0.41$

$1.029 \pm 0.39$

$1.030 \pm 0.27$

0.23

$348.8 \pm 12.8$

$294.9 \pm 7.0$

$1.014 \pm 0.64 \quad 0.41 \quad 117.4 \pm 1.0$

$0.6669+$

BR54 Base

BR54 Top

BR55 Base

$75.98 \pm 0.1 \quad 3.343 \pm 0.1$

$46.3 \pm 0.4$

$67.88 \pm 0.1 \quad 8.391 \pm 0.1$

$17.4 \pm 0.3$

$75.43 \pm 0.1$

$8.414 \pm 0.1$

$59.41 \pm 0.1$

$5.277 \pm 0.1$

$76.01 \pm 0.1$

$19.52 \pm 0.1$

BR56 Base

$87.86 \pm 0.1$

$1.920 \pm 0.1$

BR56 Top

$59.53 \pm 0.1$

$8.584 \pm 0.1$

$0.6979 \pm 2.7$

$18.9 \pm 0.3$

$0.6859 \pm 2.5$

0.46

$109.2 \pm 0.8$

$0.6716 \pm 2.0$

$0.7520 \pm 5.2$

$1.010 \pm 1.3$

0.45

$0.6760 \pm 0.59$

$060 \pm 3.6$

$121.2 \pm 1.1$

$94.1 \pm 0.3$

$0.6906 \pm 3.1$

$1.022 \pm 2.0$

0.32

(39.2 \pm 1.2

$121.5 \pm 0.9$

$125.9 \pm 1.1$

Notes:

$\dagger$ - Uncertainties quoted as $\pm 2 \mathrm{~s} \%$; \# - uncertainties quoted as $\pm 2 \sigma$ absolute; $\ddagger-\left[{ }^{230} \mathrm{Th} /{ }^{238} \mathrm{U}\right]-\left[{ }^{234} \mathrm{U} /{ }^{238} \mathrm{U}\right]$ correlation coefficient, * data and age corrected for detrital Th.

Age $(\mathrm{ka}$,

corr $)^{\# *}$

$\left.{ }^{234} \mathrm{U} / /^{238} \mathrm{U}\right]_{\mid \text {nitial }} \#^{*}$

$320.4 \pm 74.4 \quad 1.4335 \pm 0.087$

$346.0 \pm 19.3 \quad 1.0024 \pm 0.013$

$49.5 \pm 0.5 \quad 1.2309 \pm 0.004$

$102.9 \pm 0.7 \quad 0.8368 \pm 0.002$

$67.1 \pm 0.3 \quad 1.3963 \pm 0.002$

$123.8 \pm 0.9 \quad 1.0705 \pm 0.002$

$348.2 \pm 15.4 \quad 1.0785 \pm 0.009$

$294.5 \pm 7.5 \quad 1.0702 \pm 0.006$

$116.1 \pm 2.1 \quad 1.0198 \pm 0.009$

$105.9 \pm 4.4 \quad 1.1440 \pm 0.024$

$122.1 \pm 5.1 \quad 1.0205 \pm 0.022$

$118.6 \pm 4.0 \quad 1.0142 \pm 0.018$

$131.8 \pm 12.4 \quad 1.0877 \pm 0.054$

$120.8 \pm 1.3 \quad 1.0095 \pm 0.005$

$121.6 \pm 6.5 \quad 1.0314 \pm 0.029$ 